\title{
Head and Neck Cancer pN2c TNM Finding v8
}

National Cancer Institute

\section{Source}

National Cancer Institute. Head and Neck Cancer pN2c TNM Finding v8. NCI Thesaurus.

Code C132650.

Head and neck cancer with metastases in bilateral or contralateral lymph nodes, none larger than $6 \mathrm{~cm}$ in greatest dimension and ENE(-). (from AJCC 8th Ed.) 